Original research article

\title{
Preferences and influence of the value of health in the contemporary Czech population
}

\author{
Jiří Pospíšil *, Helena Pospíšilová, Ludmila Siarda Trochtová \\ Palacký University in Olomouc, Sts. Cyril and Methodius Faculty of Theology, Department of Christian Education, Olomouc, Czech Republic
}

\begin{abstract}
This paper presents the research results concerning the preferences of the value of health and whether these preferences are dependent on several social factors: gender, age, population size of the village/town/city the respondents come from, qualification level, occupation and professional orientation, family economic situation, attitudes to the public social care policy, faith in God and attitude towards religion. Research was conducted throughout the entire country using 5,425 respondents, who were asked to fill in a questionnaire. Except for one factor - attitude to the public social care policy - all of the other factors have been recognized as significantly influencing the attitude to the value of health. The results of the research have two main impacts: firstly, they support the values theory according to which we can assume the key role of values in human activity and, secondly, they could have a serious influence on today's healthcare and social care practices, because they influence the motivation of clients and consequently could support or not support the healing process.
\end{abstract}

Keywords: Attitude to health; Research; Social factors; The value of health; Values

\section{Introduction}

Health has always been an important human value. Values are often discussed (Busbee et al., 2004; Halligan, 2008; Wieten, 2015) and researched (Mangin et al., 2016) in healthcare and medicine in the context of life quality, health, healthcare and health services. To support the debate, the International Charter for Human Values in Healthcare has been established (Rider et al., 2014), and the discussion often concerns the shift from an evidence-based to values-based approach (Brown et al., 2003; Brown et al., 2005). The importance of values in healthcare is widely reflected in contemporary papers or books, and values are recognized as the key concept in the healthcare system (Marzoratti and Pravettoni, 2017). All of the discussions and research mentioned above are concerned with the values system of people as the key structure influencing the decision-making in healthcare and personal approach in the health service.

In our paper we would like to share a slightly different view on values (and especially on the value of health itself), because we claim the attitude to the value of health determines many other attitudes and beliefs as well. It is strongly influenced by both the social context and the personal qualities of any human.

Values are often the subject of research in both systematic and specific ways. From the systematic point of view, our approach to research values is highly influenced by three authors in the area of values research. The first author is the social anthropologist and sociologist Clyde Kluckhohn (1951) - who suggested a highly cited definition of values used by many authors and for whom 'a value is a conception, explicit or implicit, distinctive of an individual or characteristic of a group of the desirable which influences the selection from available modes, means, and ends of action'. In cooperation with Florence Kluckhohn and Fred L. Strodtbeck (1961), he helped to develop a values orientation theory, which started discussions concerning universal values and cross-cultural differences (Hills, 2002) and also helped to develop a values orientation approach to human concerns - including healthcare.

The second author (and the most important for us) is Milton Rokeach (1968) who recognized the nature of human values as specific kinds of attitudes. He completed the shift from values considered as a philosophical topic to the values of psychological phenomena acting as an important role in personality and personal development. Rokeach (1973) also differentiated between two basic kinds of values - terminal and instrumental. Though this difference has not been accepted by many authors, we consider it important because of its connection to values change, sources and the development of values influencing attitudes. In our research we also use the Rokeach's scales of terminal and instrumental values - although we use a different way of measurement of value's preference.

The third author who influenced the understanding, research and discussion concerning values is Shalom Schwartz (1992), who created the theory of universal values and who

\footnotetext{
* Corresponding author: Jiří Pospíšil, Palacký University in Olomouc, Sts. Cyril and Methodius Faculty of Theology, Department of Christian Education, Univerzitní 22, 77111 Olomouc, Czech Republic; e-mail: jiri.pospisil@upol.cz http://doi.org/10.32725/kont.2020.034 
recognized (together with W. Bilsky) health (1987) as part of universal requirements in the security domain.

All of the authors mentioned above argued (and successfully showed through research) that values are an important part of human lives and should be considered as important in all actions which lead to a change of life. This is why we decided to measure the specific value of health (as a part of a wider values research) and to try to analyze the change of this value and its dependency on social and personal situation.

Although health is a well-known human value, researching it could bring some difficulties. One could assume the preferences of the value of health would be very high since health is one of the most influential factors on the quality of life and wellbeing (Lelkes, 2006). This is undoubtedly right and it is also justified by common sense. Despite the assumption that the value of health is and probably will always be highly preferred, there are some differences in the preferences which could be overlooked at first glance - and which could have great meaning if we look at them in a specific social context of groups, families and individuals. All these reasons led us to include the value of health into the extensive survey of values, worldview attitudes, leisure, economic situation and ICT skills - which was conducted across the Czech Republic in the winter and spring of 2019.

\section{Materials and methods}

Research was conducted on the population of the whole of the Czech Republic using a questionnaire - which was delivered both electronically and on paper. We received replies from 5,425 respondents and the results are representative in the categories of: gender, population of city/town/village the respondents come from, and age (respondents were over 15 and all age categories divided into 10 year clusters were represented; only the category $65+$ was not limited to 10 years and has been clustered together). The sample was collected randomly with proportional stratification in categories in which it is representative.

Gender was measured using a closed categorical scale: men $(2,319,42.75 \%)$, women $(3,090,56.96 \%)$, other $(16,0.29 \%)$. Because of the very low count of respondents who identified as another gender we were not able to include this small group in the statistical testing. Therefore, we omitted the category 'other gender' in the following analyses.

We used open answers to detect age and then we split them into 10 year clusters as follows: 15-24 (1,443, 26.60\%), 25-34 (1,194, 22.01\%), 35-44 (1,020, 18.80\%), 45-54 (857, 15.80\%), $55-64(476,8.77 \%)$. Those respondents who answered age $65+$ were added into the $65+$ group $(423,7.80 \%) .12$ respondents $(0.22 \%)$ didn't answer the age question and therefore are excluded from those analyses affected by this factor.

We measured the population of the city/town/village which the respondents are from on a closed categorical scale with the following categories: less than 2,000 residents $(1,241$, $22.88 \%), 2,001-5,000$ residents $(696,12.83 \%), 5,001-15,000$ residents $(898,16.55 \%), 15,001-60,000$ residents $(1,223$, $22.54 \%), 60,001-150,000$ residents $(636,11.72 \%)$ and more than 150,000 residents $(731,13.47 \%)$.

Another researched factor was the level of qualifications. This was measured on a scale containing four options: primary education (579, 10.67\%), apprenticeship (780, 14.38\%), high school with final exam $(2,290,42.21 \%)$, and university degree $(1,776,32.74 \%)$.
Respondent's occupation was the next independent variable that we assumed as a factor influencing the preferences of the value of health. Occupation was measured on a closed categorical scale with the following options: pupil $(1,126$, $20.76 \%)$, employee $(3,068,56.55 \%)$, self-employed or other way of livelihood (412, 7.59\%), pensioner, disabled pensioner or person on maternity leave $(764,14.08 \%)$ and unemployed (55, 1.01\%).

Respondent's occupation was followed with a question concerning the professional field in which the respondent is/ was engaged in. In this question the categorical scale with the following options was used: management (387, 7.13\%), technology $(582,10.73 \%)$, medicine and healthcare $(479,8.83 \%)$, education $(814,15.00 \%)$, trade and business including accounting $(705,13.00 \%)$, public administration $(458,8.44 \%)$, information and communication technologies (293, 5.40\%), law, social care or culture (491, 9.05\%), machine operators (376, 6.93\%), unqualified work $(162,2.99 \%)$ and private or public services (e.g. craftsmen, police, army, fire brigade, gardeners) (663, 12.22\%). 15 people didn't answer this question and were therefore excluded from the following analyses using this factor.

The economic situation of the respondent's family is the next variable that we measured and assumed as a factor influencing the preference of the value of health. In this case we offered respondents five categories of economic situation: poor (the household suffers from deficiency and survives from day to day) (117, 2.16\%), not good (the household doesn't suffer from deficiency but can save almost no money) (661, 12.20\%), quite good (the household is materially secure but can't save enough money) $(2,244,41.42 \%)$, good (the household is well materially secured and can afford to save some money) $(1,898$, $35.03 \%$ ), excellent (the household is very well materially satisfied and can afford to save money) (498, 9.19\%). Seven people didn't answer this question and were excluded from the analyses with this factor.

Last but not least, the group of factors we assumed to be important for the preference level of the value of health comes from the respondent's worldview; and especially the attitude to public social care policy, faith in God and attitude to religion. We measured the first mentioned worldview factor (attitude to social care policy and level of solidarity/subsidiarity) using a categorical scale containing three possible attitudes: every person is responsible for him/herself and should look after his/her family; the government should be interested in, if and only if they are provided with a level of care which doesn't meet the expected level (2,800, $51.61 \%)$, government (state, local) should provide care adequate to the economic situation - even for people who are only potentially at risk $(1,652$, $30.45 \%$ ), and the last option - government (state, local) social care should be widely provided for all citizens and should even manage their housing, work and fair wage (969, 17.86\%). This measurement was ignored by 4 people who were excluded from the analyses of this factor. The second worldview factor (faith in God) was measured by seven categories of a closed scale. The first category was designed for those who believe God personally looks after the world (980, 18.06\%), second for those people who believe in a more divine power $(66,1.22 \%)$, third for those who believe 'something is watching over us' (1,344, 24.77\%), fourth for agnostics (990, 18.25\%), fifth for atheists $(1,386,25.55 \%)$, sixth for people who believe in a God that doesn't lead or influence the world (394, 7.26\%), and finally pantheists $(257,4.74 \%)$. Eight people didn't answer and were excluded from the analyses of this factor. The last factor measured which could influence the level of preferences 
of health is the attitude to religion. This question examined the attitude to religion as an institution/church. In the case of this factor, a scale containing four options was used and the offered answers were: I completely refuse the idea of religion (648, 11.94\%), religion could be important for some people but for me it has no meaning $(3,223,59.41 \%)$, I think of myself as a religious man/woman and I need to express my faith but I'm not a member of any religious institution/church (853, $15.72 \%$ ), and finally, I'm a religious man/woman and I belong to a religious institution/church $(694,12.79 \%)$. Seven people didn't answer this question and were excluded from the following analyses with this factor.

After all the independent variables we also measured the one we are most interested in - the preference of the health value. In the case of this variable, we used a continuous scale internally limited by 1 and 10. The measurement was provided using a line on which only extremes were described. Respondents were asked to mark a position on this line without a specified numeric value of answer. The only clue for them were margins ('this is absolutely not a value of mine, on left side'; and 'this is an absolute value of mine, it fully expresses my position'). As respondents marked their position on the line it was measured using a ruler and transformed on the scale between one and ten.

All dependences were statistically analyzed using ANOVA (Sheskin, 2011) and probability $(p)$ results of less than 0.05 were considered significant. The results less than 0.01 and 0.001 are noted, as well.

\section{Results}

The ANOVA test was provided for all factorial variables (gender, age group, population of city/town/village, level of qualification, occupation, professional orientation, economic situation of the family, attitude to social care policy, faith in God and attitude to religion). Each of these factors splits the population into groups (e.g. men and women in the case of gender, age groups in the case of age, etc.). The level of preference of the value of health was employed as the dependent variable in every ANOVA test provided. Generally, we assumed that specific population groups would have a different preference for the value of health. Every group defined by the categorical (factorial) variables mentioned above was loaded with a different average level for the value of health preference. Almost all of our assumptions have been confirmed, and the results show the preference of the value of health is significantly influenced by gender, age, population of city/town/village, level of qualification achieved, occupation, professional orientation, economic situation of families, faith in God and the attitude to religion. Only one factor, the attitude to social care policy, does not influence the attitude towards the value of health. This result is very interesting and will be discussed below. All statistical dependencies (except attitude to social care) between factors and the health value (hereinafter 'HV') were recognized as significant at least at $p<0.05$. The summary results of the ANOVA tests are presented in Table 1.

Aside from the general response to the hypothesis, the ANOVA test also brings us analytical data about the inner structure of groups - and we can see which group across the factor is most important (has the highest average preference of the value of health) and which is least important (has the lowest average preference of the value of health). This analytical data allows us to detect the group inside each factor for which the value of health is most important. Similarly, we can detect the group for which the value of health is least important. These two groups inside each factor seem to be important for building the relationship between health care specialists and those who need this care. That is the reason why we added two more columns in the results table (Table 1 ). The column 'Category with highest average preference' shows us the group for which the value of health is the most important. On the contrary, the column 'Category with lowest average preference' shows us the group for which the value of health is the least important. In the case when two groups have the same lowest or highest average preference we notice both of them.

The last information the ANOVA test brings us is standard deviation of each group within the factor being analyzed. Standard deviation helps us to understand the inner structure of each group and tells us more about the structure of preferences of the value of health within each group. Those groups with lower standard deviation are more homogenous, which we can understand as the unity of preferences of the value of health we acquired. On the other hand, the higher value of standard deviation allows us to declare the group as quite heterogenous. That means the respondents within the group have very different attitudes to the value of health and are not unique. The information concerning standard deviation of a group with the highest and the lowest preference of the value of health follows the mean and is added in brackets.

The easiest factors to report are obviously gender and attitude towards social care policy. Gender is easy because there were only two relevant categories - men and women. According to our results, women have a significantly higher preference of the HV than men. Therefore, we could consider women to be more sensitive to health affairs, and we can also state the $\mathrm{HV}$ plays a more important role in their lives than in the lives of men.

The social care policy is more complicated, not because of the results, but because it is the only factor which has no influence on the HV preference. We can only assume that the health and perception of the HV in daily life is not influenced by political preferences. It seems that people across the political spectrum consider the health issues to be very important. We can also understand this result as the difference between health and social sources of social problems. We can also postulate the hypothesis that the people might better understand and accept the existence of a health related cause for the need of social care - rather than a situation when there is 'only' a social cause for the need of social care. In this case, a health problem is more easily accepted as 'objective' trouble, while the social problem is more often considered as subjectively blamed.

Age, or age group as a factor influencing the average (hereinafter 'AVG') preferences of the HV is interesting; especially because of the evolution of the preferences as people age. The preferences rise from the age 15 to 65 , but after 65 they dramatically fall. What is even more interesting is that the rise of average preference is accompanied by a fall of the standard deviation (hereinafter 'SD'), which continuously confirms the unification of meaning of the value of health to people.

The population size of the city/town/village the respondents are from should be considered a serious factor that also has a significant influence on the HV. Although the progress in this case is not so interesting as in the previous case of age, notable numbers exist, too. Generally, the most interesting result from analyzing this factor is that the citizens of the cities with a population between 60,000 and 150,000 have a significantly lower AVG preference of the HV together with the highest SD. In other population sizes the differences are not so big, and we can say the AVG preference is slightly rising - starting at 
Table 1. Relations between social factors and preferences of the health value

\begin{tabular}{|c|c|c|c|}
\hline Factor & $p$ & $\begin{array}{l}\text { Category with highest average } \\
\text { preference (including standard } \\
\text { deviation }-s d \text { ) }\end{array}$ & $\begin{array}{c}\text { Category with lowest average } \\
\text { preference (including standard } \\
\text { deviation }-s d \text { ) }\end{array}$ \\
\hline Gender & $<0.001^{* * *}$ & $\begin{array}{l}\text { Women } \\
9.43(1.23)\end{array}$ & $\begin{array}{c}\text { Men } \\
9.08(1.54)\end{array}$ \\
\hline Age group & $0.006^{* *}$ & $\begin{array}{l}45-54 \text { and } 55-64 \\
\text { both at } 9.38 \text { (sd of } 45-54 \text { group is } 1.24 \text {, } \\
\text { sd of } 55-64 \text { group is 1.19) }\end{array}$ & $\begin{array}{c}11-24 \text { and } 65+ \\
\text { both at } 9.19(s d \text { of } 11-24 \text { group is } 1.51, \\
\text { sd of } 65+\text { group is } 1.55)\end{array}$ \\
\hline $\begin{array}{l}\text { The population of the town/village the } \\
\text { respondents are from }\end{array}$ & $0.006^{* *}$ & $\begin{array}{c}5,000-15,000 \text { residents } \\
9.40(1.20)\end{array}$ & $\begin{array}{c}60,000-150,000 \text { residents } \\
9.13(1.53)\end{array}$ \\
\hline Level of qualification & $<0.001^{* * *}$ & $\begin{array}{l}\text { University degree } \\
9.39(1.19)\end{array}$ & $\begin{array}{c}\text { Primary education } \\
9.11(1.69)\end{array}$ \\
\hline Occupation & $0.001^{* *}$ & $\begin{array}{c}\text { Pensioner, disability pensioner or person } \\
\text { on maternity leave } \\
9.32(1.39)\end{array}$ & $\begin{array}{l}\text { Unemployed } \\
8.69 \text { (1.92) }\end{array}$ \\
\hline Professional orientation & $<0.001^{* * *}$ & $\begin{array}{l}\text { Medicine or healthcare and Trade and } \\
\text { business } \\
\text { both } 9.42 \text { (sd of Medicine is } 1.26, s d \text { of } \\
\text { trade and business is 1.22) }\end{array}$ & $\begin{array}{l}\text { Machine operator } \\
9.02(1.60)\end{array}$ \\
\hline Economic situation of respondent's family & $<0.001^{* * *}$ & $\begin{array}{c}\text { Good } \\
9.31(1.36)\end{array}$ & $\begin{array}{c}\text { Poor } \\
8.54(1.93)\end{array}$ \\
\hline $\begin{array}{l}\text { Attitude to social care policy and level of } \\
\text { solidarity/subsidiarity }\end{array}$ & 0.915 & - & - \\
\hline Faith in God & $<0.001^{* * *}$ & $\begin{array}{c}\text { Those who believe there is 'something } \\
\text { watching over us' believers } \\
9.50 \text { (1.19) }\end{array}$ & $\begin{array}{l}\text { Believe in more divine powers } \\
8.95 \text { (1.67) }\end{array}$ \\
\hline Attitude to religion & $<0.001^{* * *}$ & $\begin{array}{l}\text { Religion can be important for some } \\
\text { people but for me it has no meaning } \\
9.40 \text { (1.28) }\end{array}$ & $\begin{array}{l}\text { I completely refuse the idea of religion } \\
\qquad 8.82(1.79)\end{array}$ \\
\hline
\end{tabular}

a level of 9.26 in the case of villages under 2,000 people and culminating at a level of 9.40 in the case of towns with a population between 5 and 15 thousand people. Mid-size cities (pop. 15-60 thousand) and big cities (over 150 thousand) are quite similar and the preferences are close to 9.25-9.26.

The next factor we used was level of qualification. Similarly to the age factor, the level of qualification also rises across the categories with only one exception: the rising trend of AVG level is continuous and doesn't break in the last category. The same continuous but falling trend could be observed when looking at SD.

Another interesting factor influencing the level preference of the HV is the personal occupation of the respondent. Data shows that almost all categories of respondents that are or were engaged in a responsible occupation have a higher (9.17-9.31) level of preference of the HV. On the other hand, those respondents who are unemployed (in our research only 55 people out of 5,425 ) have significantly lower preferences (8.69) of the HV. Fortunately for this group, this extremely low value is followed with the highest SD. It means that this specific group is not homogenous, and even people who have the HV preferences at a more expected level exist within it.

Before we start to analyze the factor of the professional orientation of respondents, we must emphasize that this is probably the most useful and surprising analysis published in this paper. It could help the professionals in medicine and/or healthcare to adapt their attitude to several groups of profes- sionals because of their attitude to the HV. These attitudes are probably formed over a long time and are a part of the professional identity of every person who is a professional in the analyzed fields. The results of the research are enough to prove statistical dependence, nevertheless there are no huge differences that could shock the readers and cause healthcare delivery problems for some categories of respondents. The lowest preferences of the HV is in the category of people who work as machine operators. The level of the HV preferences in this category is 9.02. When we planned the research, the hypothesis assuming the relationship between the economic situation of a respondent's family and his/her preferences of the HV was the one with possibly the greatest expectation not to be rejected. This assumption has not been disproved and now we can confirm the existence of the relationship between economic situation and preferences of the HV. Moreover, we discovered the economic situation of a respondent's family is one of the key factors influencing the HV preferences. The most important information that helps us to analyse this factor is that the respondents from families with poor and 'not good' economic situations have a lower preference of the HV. This result leads us to the conclusion that economic condition probably influences the attitude to health itself (Maskileyson, 2014).

The last two factors we ought to discuss are about faith in God and attitude towards religion as an institution/church. If we step over the special category of the few people (66) who believe in more divine powers and who have the lowest pref- 
erences of HV (8.95) we find that the category with the second lowest preference of HV is those people who believe God is looking after the world (9.04). This is much stranger when we realize the category with the highest preferences of $\mathrm{HV}$ is those who believe 'something is watching over us'. In contrast, the category of people who believe in a God which doesn't influence the world has the second highest (9.37) average preference of HV.

If we look at the last researched factor influencing the preferences of $\mathrm{HV}$ - the attitude towards religion - we find further surprises. The category of respondents who refuse religion has the lowest level of preferences of HV (8.82). This is contradictory to the previous findings concerning atheism and the belief in a God that does not influence the world. The contradiction looks even deeper when we realize the highest level of preferences of the HV (9.39) was measured in the people who think religion could be helpful for somebody, but has no value for them. In the discussion we will try to form an explanation for this discrepancy. The last two categories - those who consider themselves as religious and don't belong to a religious institution/church, and those who are members of a church or any other kind of religious institution, conformed to the previously measured attitudes to belief in God. With their membership in a religious church/institution they have a remarkably lower level of preference of HV.

\section{Discussion}

The main goal of this paper was to examine the influence of several social factors on the preferences of HV among the contemporary $\mathrm{Czech}$ population. The results of the research show that almost all of the selected factors except one - the attitude to social care policy and level of solidarity/subsidiarity - have a significant influence on $\mathrm{HV}$.

If we start the discussion with gender and age groups, we could state the results of our research are not surprising; many authors have found significant differences between men and women or among different age groups in values research (e.g. Vilar et al., 2020). Heckhausen et al. (2010) argue that people change and adjust their values, expectations, and attributions in accordance with proto-typical opportunities (and constraints) common in different stages of the life span. In general, these results (from worldwide research studies) confirm our results concerning gender and age and also the change across the life of humans (Dobewal et al., 2017). In the case of $\mathrm{HV}$ we are not able to compare our results directly with others, because HV is almost always measured as a part of a certain value or motivational domain, but we can confirm the trend in values shift.

Both gender and age were factors measured and discussed, not only for influential results, but also because our research was designed to be representative in these categories. Instead of these two categories the research was designed and realized to be representative of the Czech population in one more category. This category is the population of the town or village in which the respondents live. Thanks to this category we can confirm the research represents the whole of the Czech population - especially since we know that more than $27 \%$ of the population live in small villages, about $30 \%$ of the population live in small cities, approximately $21 \%$ of the population live in towns smaller than 100000 inhabitants, and over 22\% live in big cities (Czech Statistical Office, 2011).

It seems reasonable to assume that the importance of $\mathrm{HV}$ will rise together with qualification level. Our findings proved (with statistical significance) the connection between preference of $\mathrm{HV}$ and level of qualification, and we can also confirm previous findings published by Colby et al. (2010) or Soria and Mitchell (2016). Formal and probably also informal and non-formal education is making a stronger connection between these phenomena. We can also assume that the reason for the rising level of the preferences of HV with tertiary education is also related to the higher level of both civic and personal responsibility.

As we mentioned in the research results, the preference of $\mathrm{HV}$ is higher in those respondents who are/were engaged in responsible occupations. It is not surprising that the group of pensioners, disability pensioners and persons on maternity leave has the highest preferences of HV; for these people health is very important and brings them daily concerns. When we compare these results with previous findings concerning age groups, we can see quite a strange contradiction because respondents aged $65+$ declared the lowest preferences of $\mathrm{HV}$. Surely one can argue that the group of pensioners also includes those who are disability pensioners and people on maternity leave, but these subgroups do not explain such a big difference. Fortunately, there exists another explanation. Pensioners in the Czech Republic are people who have achieved the age of about 63 and pensioners who are younger than $65+$, and together with disabled pensioners and people on maternity leave they significantly influenced the group we are discussing. This influence also confirms the fact that the respondents in the age group 55-64 have the highest preferences of HV among all of the age groups. It is important to discuss the category of unemployed people (similar to poor people) who reported the lowest preferences of HV because we found an interesting connection with self-reported health status. Johansson et al. (2020) published a study in which they confirmed the relationship between self-reported health status and unemployment. Another interesting fact is that biometric measurements did not confirm this connection.

In the case of professional orientation, there are differences which allow us to distinguish three groups of professionals: those with a higher sensitivity towards health, those with a medium sensitivity for health and the last with a lower sensitivity for health. Due to the higher preferences of HV, the first group (professions with a higher sensitivity for health) includes medicine and other healthcare professionals, trade and business (including accounting) professionals, and officials working in public administration. The second group (professions with a medium sensitivity for health) is made up of professionals in the field of education and private and public services professionals (e.g. craftsmen, police, army, fire brigade, gardeners). The third group of professions (the one with a lower sensitivity for health) consists of professionals in management, technology, law, social-care culture, machine operators, and finally those people who work in positions with no demands for qualifications.

The influence of the economic situation of the family shows a paradox which could be easy overlooked, but we wonder if it could have important consequences. It is a fact that families with an excellent economic situation have a slightly lower preference of HV than those families with a good or quite good economic situation (although there is no rational reason for this fall). Although we are not fully able to explain this surprising change, it could be interesting to compare this result with the research concerning fundamental drivers of prosperity in the EU and Western Balkan Countries (Gavrilović and Gligorić, 2018) where the different prosperity drivers are discovered for different groups of countries. The Czech Republic has also 
been included in this research, and according to the results it is among the countries for which education and safety are the most important drivers of prosperity. So, we could deduce that most prosperous people with a higher income have different preferences of HV than for example people in those EU countries which are richer (Finland, Denmark, Austria, etc.).

The factor of faith in God is the most confusing of all. It could be considered a paradox, but the category of those who believe 'something is watching over us' has the highest level of preferences of HV, whilst the category of 'believers in a personal God who is looking after the world' has the second lowest preferences of HV. The only reasonable explanation of these preferences is that the people whose faith in God or powers which control our actions do not care so much about their health and therefore have a lower preference of HV. Their faith in God gives them hope and replaces the other values (Nicholson et al., 2010). On the other hand, the people who do not believe in God (atheists) or who believe in a God that doesn't care, carry much more responsibility on their own shoulders and they have to deal with it alone. This is why they consider health to be the ultimate value and no value is more important for them. This is not only a problem of theory of values but it is also a theological problem (Collins, 2018).

From the point of view of the previously analyzed factor, it might be clear why the factor of attitude towards religion might look confusing. However, the situation here is quite different. The respondents with the lowest preferences of HV here are those who stated the negative attitude to any religion. The only acceptable explanation is that the attitudes to religion as an institution/church do not match the attitudes concerning belief in God (Hammer, 2018). Even if we explain the differences to the previous question another question still remains: why do those people who refuse religion have such a low level of preferences of HV? One possible answer is that the attitude to institutional religion is connected with a general distrust in institutions (especially religious - Vido, 2019) and the HV specifically points out and represents the complexity of societal institutions who serve to provide health, medical and social care (Palmer Kelly et al., 2019). This opinion could be supported by another result concerning attitudes to religion in the relationship with $\mathrm{HV}$, namely the highest level of preferences of HV (9.39) which has been measured among people who think religion could be helpful for some, but has no value for them.

\section{Conclusions}

In this paper we have discussed several proven relationships between social factors and preferences of the HV. The results achieved in our research bring new stimuli for both theory of values and the practice of healthcare.

From the point of view of the values theory, we could state there exist newly discovered relationships and factors influencing the constitution of values and setting the level of values preference. The health value represents only a small part of the personal values orientations, but it can help us to understand how this little piece of an individual's world of values is being influenced and formed. The question is how (and whether) the level of preference of the HV influences factors mentioned above and the relationship is linked. Our previous findings concerning values and leisure confirm this assumption - although the statistical methods used in this research and published in this paper do not allow us to proclaim these results.

From the point of view of the practice of healthcare we can confirm the important role of values in every day care, because the values play an important role in the clients'/patients' worldview and their attitude to care which is delivered to them. The attitude to health (represented by the HV) in the lives of clients can be a crucial factor that can change the motivation of a client - and consequently could lead to them healing or not healing. The source of client motivation is hidden in his/her inner world and the only way to use it in the process of healing is to understand values as representations of these motivations. Maybe we will not use the specific factors analyzed in this paper (and even the value of health itself) for immediate change, but we hope they will be considered as important - because we believe this could lead to a change in healthcare and social care in the long run.

\section{Conflict of interests}

The authors have no conflict of interests to declare.

\section{Acknowledgement}

Publishing of the paper and the research has been supported by Internal Grant Agency of Palacký University in Olomouc, grant no. IGA_CMTF_2019_008.

\title{
Preference a vliv hodnoty zdraví v současné české populaci
}

\begin{abstract}
Souhrn
Článek prezentuje výsledky výzkumu zaměřeného na preference hodnoty zdraví a sociální faktory, které tyto preference ovlivnuují. K těmto faktorům patří především pohlaví, věk, velikost obce, úroveň dosaženého vzdělání, profesní orientace, ekonomická situace rodiny, postoje k sociální politice, víra v Boha a postoj vůči náboženství. Výzkum byl realizován napříč Českou republikou a zúčastnilo se jej 5425 respondentů. Data byla získána pomocí dotazníku. Výzkum prokázal, že na postoj k hodnotě zdraví mají významný vliv všechny sledované faktory s výjimkou postojů k sociální politice státu. Provedený výzkum přináší dva hlavní důsledky pro teorii i praxi sociálních věd: podařilo se potvrdit význam hodnot v kontextu sociálního statusu a postojů a také prokázat významný vliv hodnot pro praxi současné zdravotní a sociální péče, protože hodnoty ovlivňují motivaci klientů a v důsledku toho mohou významně prospět procesu uzdravování, nebo mu naopak uškodit.
\end{abstract}

Kličová slova: hodnota zdraví; hodnoty; postoj ke zdraví; sociální faktory; výzkum 


\section{References}

1. Brown GC, Brown MM, Sharma S (2003). Value-based medicine: evidence-based medicine and beyond. Ocul Immunol Inflamm 11(3): 157-170. DOI: 10.1076/ocii.11.3.157.17355.

2. Brown MM, Brown GC, Sharma S (2005). Evidence-Based to Value-Based Medicine. Chicago: AMA Press, 339 p.

3. Busbee BG, Brown GC, Brown MM (2004). Value-based medicine: a new paradigm to evaluate treatments for vitreoretinal diseases and other medical interventions. Int Ophthalmol Clin 44(4): 155-172. DOI: 10.1097/00004397200404440-00012.

4. Colby A, Beaumont E, Ehrlich T, Corngold J (2010). Educating for democracy: Preparing Undergraduates for Responsible Political Engagement. San Francisco: Jossey-Bass.

5. Collins GP (2018). The atheist problem of disease: Who's to blame? Theology 121(2): 92-95. DOI: 10.1177/0040571x17740524.

6. Czech Statistical Office (CZSO) (2011). Obyvatelstvo podle velikostních skupin obcí a podle hlavních charakteristik. [online] [cit. 2020-08-20]. Available at: https://www.czso.cz/ documents/10180/24358877/240001302.pdf/

7. Dobewall H, Tormos R, Vauclair C-M (2017). Normative Value Change Across the Human Life Cycle: Similarities and Differences Across Europe. J Adult Dev 24(4): 263-276. DOI: 10.1007/s10804-017-9264-y.

8. Gavrilović Jovanović B, Gligorić M (2018). Fundamental drivers of prosperity in the European Union and Western Balkans countries. Industry/Industrija 46(1): 155-171. DOI: 10.5937/ industrija46-16696. ISSN 03500373.

9. Halligan A (2008). The importance of values in healthcare. J R Soc Med 101(10): 480-481. DOI: 10.1258/jrsm.08k019.

10. Hammer CB (2018). Mutuality, Integration, and Collaboration: A Spiritual Awakening for the Twenty-First Century. International Congregational Journal 17(1): 91-101.

11. Heckhausen J, Wrosch C, Schulz R (2010). A Motivational Theory of Life-Span Development. Psychol Rev 117(1): 32. DOI: $10.1037 / \mathrm{a} 0017668$.

12. Hills MD (2002) Kluckhohn and Strodtbeck's Values Orientation Theory. Online Readings in Psychology and Culture 4(4). DOI: 10.9707/2307-0919.1040.

13. Johansson E, Böckerman P, Lundqvist A (2020). Self-reported health versus biomarkers: does unemployment lead to worse health? Public Health 179: 127-134. DOI: 10.1016/j. puhe.2019.10.005

14. Kluckhohn C (1951). Values and value-orientations in the theory of action: An exploration in definition and classification. In: Parsons T, Shils E (Eds). Toward a general theory of action. Cambridge, MA: Harvard University Press.

15. Kluckhohn FR, Strodtbeck FL (1961). Variations in value orientations. Evanston, IL: Row, Peterson.

16. Lelkes $O$ (2006). Tasting freedom: Happiness, religion and economic transition. J Econ Behav Organ 59(2): 173-194. DOI: 10.1016/j.jebo.2004.03.016.
17. Mangin D, Stephen G, Bismah V, Risdon C (2016). Making patient values visible in healthcare: a systematic review of tools to assess patient treatment priorities and preferences in the context of multimorbidity. BMJ Open 6: 1-9. DOI: 10.1136/ bmjopen-2015-010903.

18. Maskileyson D (2014). Healthcare system and the wealthhealth gradient: A comparative study of older populations in six countries. Soc Sci Med 119: 18-26. DOI: 10.1016/j. socscimed.2014.08.013.

19. Marzoratti C, Pravettoni G (2017). Value as the key concept in the health care system: how it has influenced medical practice and clinical decision-making processes. J Multidiscip Healthc 10: 101-106. DOI: 10.2147/JMDH.S122383.

20. Nicholson A, Rose R, Bobak M (2010). Associations between different dimensions of religious involvement and self-rated health in diverse European populations. Health Psychol 29(2): 227-235. DOI: 10.1037/a0018036.

21. Palmer Kelly E, Hyer M, Payne N, Pawlik TM (2019). A mixedmethods approach to understanding the role of religion and spirituality in healthcare provider well-being. Psychol Relig Spiritual [in print]. DOI: 10.1037/rel0000297.

22. Rider AR, Kurtz S, Slade D, Esterbrook Longmaid III H, Ho M-J, Kwok-hung Pun J, et al. (2014). The International Charter for Human Values in Healthcare: An interprofessional global collaboration to enhance values and communication in healthcare. Patient Educ Couns 96(3): 273-280. DOI: 10.1016/j. pec.2014.06.017.

23. Rokeach M (1968). Beliefs, attitudes, and values: a theory of organization and change. San Francisco: Jossey-Bass.

24. Rokeach M (1973). The nature of human values. New York: Free Press.

25. Schwartz SH (1992). Universals in the content and structure of values: Theoretical advances and empirical tests in 20 countries. In: Zanna MP (Ed.). Advances in experimental social psychology 25: 1-65. Academic Press. DOI: 10.1016/S00652601(08)60281-6.

26. Schwartz SH, Bilsky W (1987). Toward a universal psychological structure of human values. J Person Soc Psychol 53(3): 550-562. DOI: 10.1037/0022-3514.53.3.550.

27. Sheskin DJ (2011). Handbook of parametric and nonparametric statistical procedures. Boca Raton: CRC Press.

28. Soria KM, Mitchell TD (2016). Civic engagement and community service at research universities: engaging undergraduates for social justice, social change and responsible citizenship. London: Palgrave Macmillan.

29. Vido R (2019). Jak (ne)vysvětlit českou bezbožnost? Analytická sociologie jako inspirace pro sociologii náboženství. Sociológia 51(4): 420-443. DOI: 10.31577/sociologia.2019.51.4.19.

30. Vilar R, Liu JH, Gouveila VV (2020). Age and gender differences in human values: A 20-nation study. Psychol Aging 35(3): 345-356. DOI: $10.1037 /$ pag0000448.

31. Wieten S (2015). What the patient wants: an investigation of the methods of ascertaining patient values in evidence-based medicine and values-based practice. J Eval Clin Pract 24(1): 8-12. DOI: 10.1111/jep.12471. 